\title{
A Study on Occupational Health and Safety Practices in Bangladeshi Leather Industry
}

\author{
Shilpy Rani Basak*, Ismail Raihan, Abu Sayed Bhuiya \\ Department of Civil and Environmental Engineering, SUST, UNIDO (United Nations Industrial Development Organization), \\ Dhaka, Bangladesh \\ Email: *shilpy_basak@yahoo.com
}

How to cite this paper: Basak, S.R., Raihan, I. and Bhuiya, A.S. (2019) A Study on Occupational Health and Safety Practices in Bangladeshi Leather Industry. Journal of Human Resource and Sustainability Studies, 7, 302-311.

https://doi.org/10.4236/jhrss.2019.72019

Received: March 15, 2019

Accepted: June 23, 2019

Published: June 26, 2019

Copyright $\odot 2019$ by author(s) and Scientific Research Publishing Inc. This work is licensed under the Creative Commons Attribution International License (CC BY 4.0).

http://creativecommons.org/licenses/by/4.0/

\begin{abstract}
Most of the people know the most common rules and regulation but very few obey them. Different injuries are the common scenario in small, medium and big industries. Statistics show $50 \%-60 \%, 5 \%-10 \%$ and $35 \%-40 \%$ of injuries occurred due to the unconsciousness of workers, mechanical problems and carelessness of owners respectively. This paper based on some practical working report of Re-Tie Bangladesh, UNIDO and finally some recommendations are provided for policy management in health and safety issues in industries. To improve Occupational Health \& Safety (OHS) situation in the industries in an effective way there should set some specific target for owners and workers. The main reason for injuries or accidents in workplace is both workers and owners are not habituated with some rules, regulations and moral duties. The study finds out that minimum treatment expenses for an injured worker is $0.05-0.2$ million BDT which is 9 to 36 times more than yearly expenses for PPE (Personal Protective Equipment) required for each worker [1]. Though it is quite impossible to change the practice and tradition of a long time over night, it is high time to think of the matter to compete in international market with international standards. The cost to promote good working environment and OHS status has an effect on production cost but one thing needs to keep in mind that, good workplace; skilled, safe and healthy workers are profitable in the long run.
\end{abstract}

\section{Keywords}

Sustainable, Injury, Occupational Health and Safety, Tannery

\section{Introduction}

In developing Bangladesh, leather industry is one of the biggest sectors for the economic growth of the country. But one of the main shortcomings of this sec- 
tor is that Occupational Health and Safety (OHS) rules are not properly maintained in the leather industries. This carelessness to OHS in compliance issue will be the main challenge for the sustainability of Bangladeshi leather Industries in the competitive world market.

The reduction of environmental threats and increase of the export potential of Bangladeshi leather products (Re-Tie Bangladesh) is a project co-funded by the European Commission [2]. This is under the SWITCH Asia programme and implemented by the project partners: SEQUA (lead partner), BFZ, BFLLFEA, BTA, DCCI and UNIDO for three years. An extensive research has been carried out by the project on OHS sector in leather industries of Bangladesh [2]. This paper is based on the working report of this project.

Bangladesh's leather sector is deemed competitive because of its low labor cost differentiation, local availability of hides and a favorable business environment. This is complemented with the existence of organizations and institutional arrangements like the Export Processing Zone (EPZ) etc. and duty-free access to major international markets [2].

To be fitted with the international standards, the Government is decisive to put laws on tanneries to adopt sustainable practices in a satisfactory environment. So, this is the high time to build up consciousness on OHS issues both in owners and workers level.

\section{Literature Review}

Many Researchers all over the world have done researches on occupational health and safety issues. Some findings are listed below:

Occupational health as a science concerned with health in its relation to work or working environment [3]. According to Oxenburgh et al., the health and safety of all employees is closely linked to the company's productivity in all workplaces [4].

In most cases, occupational health safety (OHS) is largely measured by negative outcomes such as workplace injury and illness but these measures have a shortfall, for instance, a low incidence of injury does not necessarily mean that adequate safety systems and controls are in place [5].

Kumar et al. demonstrated the involvement of hazards and risk in the spinning and ginning industries. They found that main hazards were noise, dust, fire and electrical hazards which was found by calculated RPN (Risk priority number) number, comparing to other hazards the maximum RPN was found to be harmful to the workers. The study recommended to take immediate action to control these hazards to save workers health and promote safety to worker [6].

According to Islam et al. working environment, types of work, way of work, smoking, use of PPE and lifestyle has a great impact on the health of the tannery workers. Smoking and household income of the respondents were found significantly associated with the morbidity of the tannery workers. The study strongly recommended for strict enforcements of Bangladesh's Labour Act (2006) along 
with more concern on OHAS (Occupational health and safety) issue for both government and tannery employers as soon as possible. The study also suggested for exclusive hospital, proper training focusing on PPE use and chemicals along with safe housing for tannery workers [7].

According to Öztaş et al. [8], the performance of a system must be monitored with appropriate indicators, otherwise the investment is wasted.

Increasing awareness of the adverse effects of occupational accidents and diseases on workers and workplaces has led to the increasing enforcement of preventive measures to combat risks [9].

Katsuro, et al. recommended that food industry factories should upgrade their OHS through training programmes and use up-to-date equipment. The objective of the study was to explore OHS problems of different work areas and their impact on productivity [3].

Biswas et al. investigated the causes of workers' health problems which were integrated with their daily work in the tanning industry, and with their daily life style pattern. The paper illustrated that chemical and risk is a stagnant theme. The actors decide the frequency of chemical exposure and risk. The paper also showed that society and culture create the working place conditions which have great impact on workers' health [10].

Considering the geographical aspects, Occupational Health hazards among the workers of tannery industries are not only a matter of concern in developing country like Bangladesh but also in western countries as well. Studies of leather-tannery workers in Sweden and Italy found cancer risks between $20 \%$ and $50 \%$ of the workers which is above expectation in case of their developed and safer health conditions of their inhabitants [11].

From the above discussion it can be concluded that most of the papers mostly focuses on work place hazards and their impact on worker's health condition but this study mainly view those issues in a different dimension. The study tried to find out the picture which shows that OHS practices are not only save worker's life but also profitable for business.

\section{Assessment of OHS Condition in Tanneries}

\subsection{Identified Problem/Hazard}

It is the common scenario that all the Machinaries, electric panel \& boards are not properly protected and the workers of tanneries are working in Hazaribagh without personal protective equipments in all most all tanneries, consequently major/minor accidents are being occurred in a regular basis in the tanneries. From the field survey of UNIDO expert team it was observed that in the year 2010, 13 number of people have been died from accident (gas poisoning, electrified), 30 people have been injured seriously (Hospitalized due to leg/hand breaking, acid burn) either in their hand or leg and 19 people have been injured (loss of 1 finger, senseless etc.) in different tanneries of Hazaribagh. Among them $12,3,12,5,2$, and 12 numbers of workers had lost their hand, leg, finger, 
burned from acid \& hot water, electrified and senseless from gas poisoning \& over heat respectively and the remaining three were injured from other occurrences respectively [1]. Main reason behind this huge number of accident is lack of awareness both in workers and owners and absence of health safety practices with appropriate safety guards in sensative machinaries, electric points and poor electric wiring as well.

\subsection{Three Major Areas for Injuries}

UNIDO expert team made two years continuous survey with practical data analysis and identified three major areas for injuries in Tanneries as shown in Figure 1. So, Health and Safety issues are strongly need to be considered in this area. First field of accident or injury prompt zone is for chemical section. This area covers chemical storage, chemical distribution, different leather tanning processes. According to technical report of UNIDO about 20\% to $30 \%$ injuries occur in this area (Table 1). As tannery industries are heavy industry, they use heavy machineries almost all stages of their production. But it is matter of great regret that many of them are not operating according to the safety manuals. Sensors are not useable in about $45 \%$ cases of the machineries. Lack of knowledge of proper maintenance is one of the reasons that UNIDO special team found. For this reason, the highest risk of accident is conducting in mechanical zone (Table 1). The team calculated over 50 of industries and got about $60 \%$ to $70 \%$ of injuries are in Bangladeshi tanneries in Machineries department (Table 1). The electrical setup is the poorest in maximum Tanneries. Unplanned wiring, over using load open phase electrical installation etc. are the main cause of the accident events. It was assessed that about $10 \%$ to $15 \%$ of injuries are happened for poor electrical condition of the industry as mentioned in Table 1.

Some pictures of hazards in different zone of tanning process are shown in Figure 1.



Figure 1. Three major accident-prone areas: Chemical, Mechanical and Electrical. Source: Rongved, 2011 [12].

Table 1. Assessment of field/area and reasons of injuries in the tannery.

\begin{tabular}{cccc}
\hline & \multicolumn{2}{c}{ Percentage of injuries } \\
\hline Area/Field of injuries & $\%$ & Main reasons & $\%$ \\
Mechanical & $60-70$ & Lack of awareness of workers & $50-60$ \\
Chemical & $20-30$ & Mechanical problem & $5-10$ \\
Electrical & $10-15$ & Carelessness of owners & $35-40$ \\
\hline
\end{tabular}




\section{Solution of Problem/Hazard}

It is not very easy or practical to improve the condition of Health and Safety of Hazaribagh tanneries in short time. Still now there is no imposed law of compliance on labor health and safety issues from the Government to the tannery owners. So, the owners or managers do not feel any pressure legally. On the other hand, the working environment and health and safety issue in leather Garments and Footwear is just opposite to the tannery. The interesting news is that every footwear industry owner has their own tannery in Hazaribagh. So firstly, need to set a genuine compliance guideline and by law impose it to the industries. After that there must have some provision to follow safety practices, awareness build up, over and over follow-up for practicing safety materials and to make it habituate to the labors are important. It is better to make people acquainted with some simple rules of consciousness, responsibility and obedience and that can stop huge damage as well. To make people aware there should have some better evidence which can help to build self-awareness both in workers and owners' level.

\subsection{Some Improvement Introduced to Tanneries on Health and Safety Issues}

Different steps were taken by the Re-tie Bangladesh, UNIDO team for improving health and safety conditions of Hazaribagh tanneries. Such as Awareness build up program, Campaigning, managers workshop, Parsonal Protective Equipment (PPE) distribution with practical demonstration about benefits of using equipment, updated technology for Machinaries maintainance, Booklets preparation as user manuals, electrical guard set up, Machinaries guard installation in risky zone (Table 2), Demonstrations of proper way for chemical storage and distribution, using Safety sign, using first Aid box, etc.

\subsubsection{Main Contents of the Booklet}

The booklet prepared by the UNIDO team is a useful one. The booklet will be helpful for improving OHS status in the long run as well. The Booklet contents are listed below:

$>$ Present health status of Tannery workers in Hazaribagh;

$>$ Probable health hazard from Chemical used in leather processing;

Probable health hazard from Machineries used in leather processing;

Probable health hazard in different leather processing unit;

$>$ Preliminary mesures, how to prevent health hazard during working in Tannery;

Instruction about an ideal chemical store;

Instruction about general health safety for both owners and workers;

Maintenance checklist for better working environment;

This booklet will help both tannery owners/managers and workers to follow the precaution measures and to improve qualitative production as well. 
Table 2. Improvement of selected risky spots.

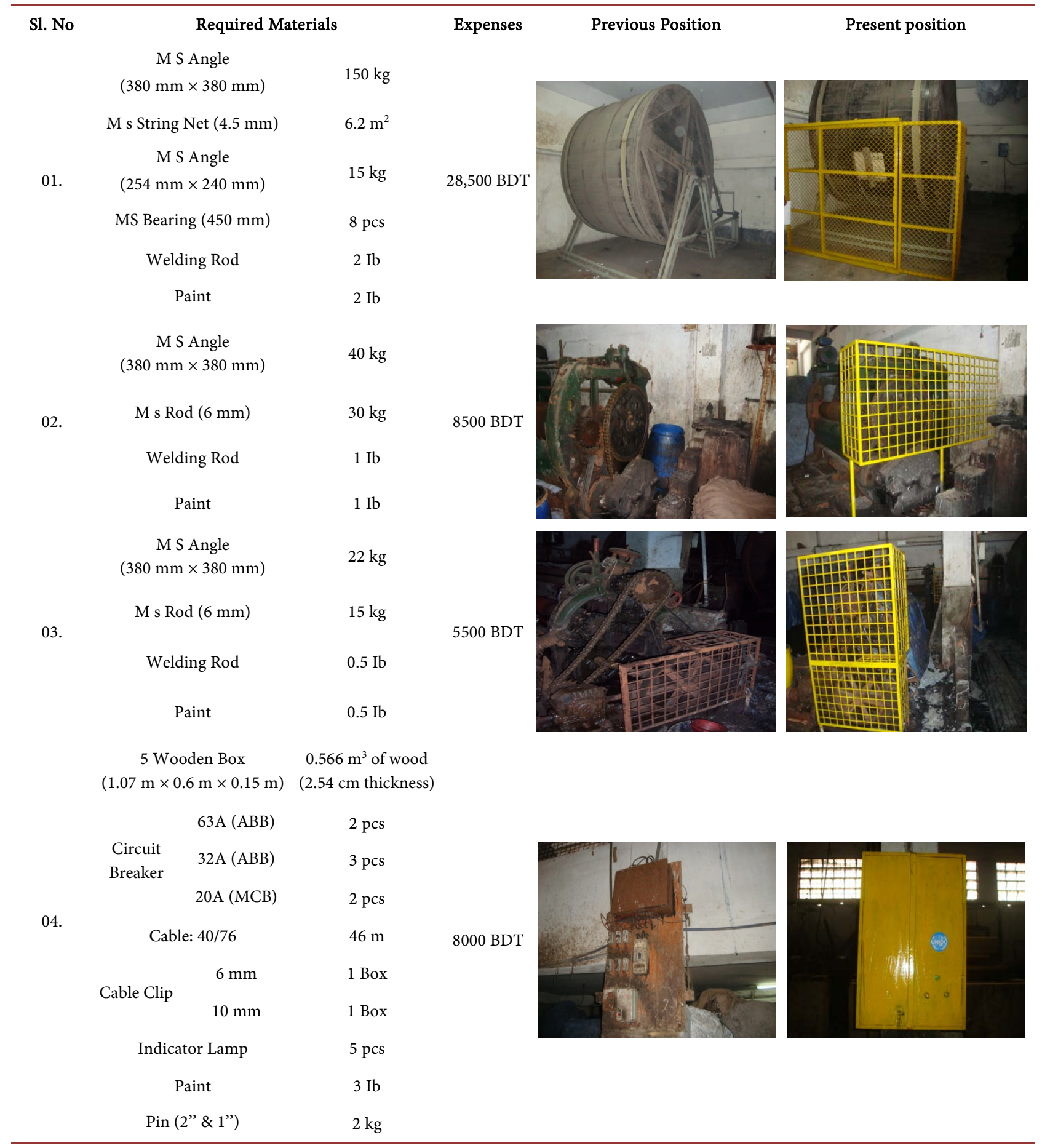

\subsubsection{Main Theme of the Posters}

Some posters were prepared by the expert team to aware workers/managers about safety issues. The main themes of those are:

Motivational dialogues to inspire people for wearing PPE;

$>$ Photo graphic presentation about what to do and not to do;

Inspire people to handle chemical carefully and to be consious during work. 


\subsubsection{Inserting Safety Guards with Some Risky Machienaries and Electric Boards}

UNIDO expert team was done some practical interventions to demonstrate the owners and managers how some simple improvements can be done, like as guards, boxes insulation etc., which can reduce the tendency of accident or rate of injuries enormously. On the other way those are not much expensive also. As for example, just improving safety guards in a very simple and inexpensive manner reduces the percentage or the probability of serious injuries. The fact is that only mind set can change the scenerio, no matter what the cost is. Some practical improvement works were done by expert team of Re-tie Bangladesh, UNIDO are shown in Table 2. Table 2 shows the previous conditions of some bared mechanical instruments side by side it is showing the modified versions. The cost of modifications and required materials are also listed there in Table 2.

\section{Benefits of Getting Upgrade}

In fact this limited number of safety guards is not sufficient to save all the workers of Tannery Industry. But this simple example can be a model. Protection of one worker from an accident means saving at least a family with 5 to 8 people in Bangladesh aspect. Again a skilled worker is an asset for the industries. To lose an effective worker is also a loss for them in their point of view. So its economic value can never be evaluated in a monetary form. Even it is tough to establish linear mathametical equation to determine loss and benefit due to an accident in a work place with respect to production of a factory. But emperically it can be compared between expenses for health and safety measures and gross production cost and sale of a factory (Figure 2).

Finally, the expert team of UNIDO from their practical survey experiences made calculations of three major areas of OHS measures and did a comparative calculation of production cost and benefit in a gross Table 3. For a green growth committed industry the following table would be more helpful to invest first for getting more benefit.

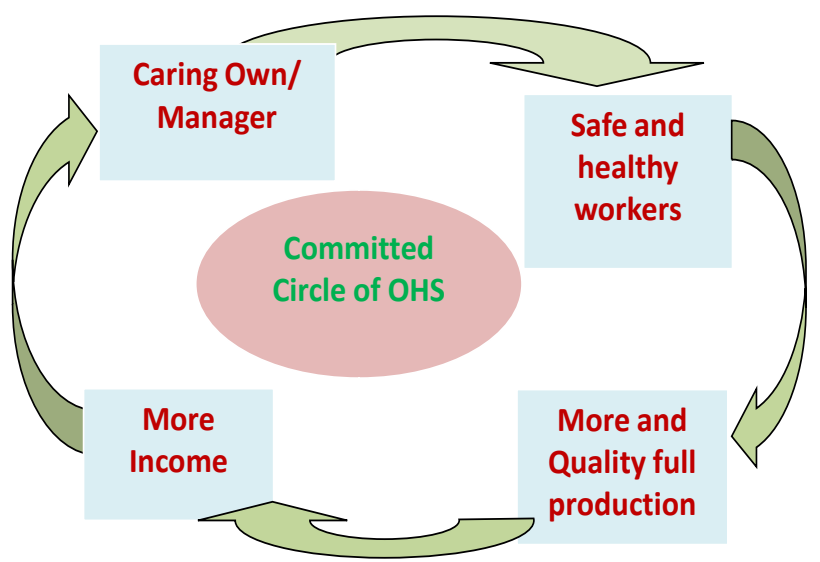

Figure 2. Flow diagram of OHS establishment and benefit of the owners. 
Table 3. Final analysis.

\begin{tabular}{|c|c|c|c|c|c|c|c|c|}
\hline $\begin{array}{l}\text { Yearly Expenses } \\
\text { (BDT) for Safet } \\
\text { Measures }\end{array}$ & & $\begin{array}{l}\text { Average } \\
\text { Production } \\
\text { Capacity }\end{array}$ & $\begin{array}{l}\text { Average } \\
\text { Yearly } \\
\text { Production } \\
\text { Cost }\end{array}$ & $\begin{array}{l}\text { Increment of } \\
\text { average Yearly } \\
\text { Production } \\
\text { Cost due to } \\
\text { Safety Measures }\end{array}$ & $\begin{array}{l}\text { Average } \\
\text { Yearly } \\
\text { Sale }\end{array}$ & \multicolumn{2}{|c|}{$\begin{array}{l}\text { Average Net } \\
\text { Profit from } \\
\text { Production } \\
\text { (BDT) }\end{array}$} & Remarks \\
\hline $\begin{array}{l}\text { Safety } \\
\text { Measure }\end{array}$ & Expenses & & & & & $\begin{array}{l}\text { Without } \\
\text { Safety }\end{array}$ & $\begin{array}{l}\text { With } \\
\text { Safety }\end{array}$ & $\begin{array}{l}\text { Loss of owner } 1.72 \text { million } \\
\text { BDT }(0.024 \%) \\
\text { But }\end{array}$ \\
\hline $\begin{array}{l}\text { PPE for } \\
\text { Workers }\end{array}$ & 0.35 million & 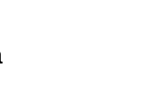 & & & & & & $\begin{array}{l}\text { An injured worker whose } \\
\text { yearly average salary is } \mathbf{0 . 0 4 8}\end{array}$ \\
\hline $\begin{array}{l}\text { Safety } \\
\text { Guard with } \\
\text { Machines/Parts }\end{array}$ & 0.74 million & $\begin{array}{l}3.6 \text { million } \\
\text { sq. } \mathrm{ft} / \mathrm{yr} \text {. }\end{array}$ & $\begin{array}{l}540 \text { million } \\
\text { BDT }\end{array}$ & $\begin{array}{l}{[540+(0.35+0.74+0.64)]} \\
=541.72 \text { million } \mathrm{BDT}\end{array}$ & $\begin{array}{l}612 \\
\text { million } \\
\text { BDT }\end{array}$ & $\begin{array}{l}72.00 \\
\text { million }\end{array}$ & $\begin{array}{l}70.28 \\
\text { million }\end{array}$ & $\begin{array}{l}\text { million BDT he ought to } \\
\text { expense } 0.05-0.2 \text { million of } \\
\text { BDT as treatment cost, besides } \\
\text { this he loses his efficiency, } \\
\text { working capacity and becomes }\end{array}$ \\
\hline $\begin{array}{l}\text { Safety Guard in } \\
\text { Electric Board }\end{array}$ & 0.64 million & & & & & & & $\begin{array}{l}\text { burden to family and society. } \\
\text { And the sector loses an } \\
\text { experienced worker. }\end{array}$ \\
\hline
\end{tabular}

\section{Conclusion and Recommendations}

At present most of the tannery industries of Hazaribagh have been shifted to new Savar Tannery estate. So, the owners and managers should have some modern practices or OHS provision in new site for creating better working environment. And to have a consistent good result, everyone should grip the new ideas, and modern concept just from now. Because today's starting of using OHS concept will make today's workers more efficient and professional in future. Around the world the cost of labor price goes up in very multiplying figure. Though still now it is cheap in our country but the fact will change soon. Bangladesh is one of the fastest favorite countries to the investors to finish leather products and footwear both in countrywide and abroad. So, by adopting the truth and to compete in the world market the owners should need to come forward to be updated on OHS sector as it is one of the burning issues for green growth of an industry. The study reveals that UNIDO has worked substantially in the OHS issues for the leather sector and summarized their result for the owners and managers that use PPE, safety guard installation, safe chemical handling, and electrical installation, not cost the production loss. At the same time in the long run it increases the product value for the market and ensures the factories sustainability as well.

Some recommendations also can be set as:

> Government has to be caring and strict in proper application and regular monitoring/follow up of industrial and labor laws.

Dwners have to be caring to their workers; they have to consider the workers as their assets.

All buyers (especially foreign) should follow and strict about the social compliance as one of the mandatories of their dealings.

- Labor Union has to play vital role to be aware of workers about health safety.

> Training, campaigning and short drama show such awareness building program has to be organized more frequently and regularly. 
So, by providing input positively following the OHS practices can build a commitment towards sustainable tannery industry of Bangladesh.

\section{Acknowledgements}

UNIDO, Re-tie Bangladesh Project for giving permission to make publication write up.

\section{Conflicts of Interest}

The authors declare no conflicts of interest regarding the publication of this paper.

\section{References}

[1] Barbieri, S.S. (2011) UNIDO Technical Report on Occupational Health and Safety in Hazaribagh, Dhaka, Tannery Cluster', Re-Tie Bangladesh, UNIDO.

[2] Paul, H.L. (2013) Bangladeshi Leather Industry: An Overview of Recent Sustainable Developments. Journal-Society of Leather Technologists and Chemists, 97, 25-32.

[3] Katsuro, P., Gadzirayi, C.T. and Mupararano, S. (2010) Impact of Occupational Health and Safety on Worker Productivity: A Case of Zimbabwe Food Industry. African Journal of Business Management, 4.

[4] Oxenburg, M., Marlow, P. and Oxenburg, A. (2004) Increasing Productivity and Profitability through Health and Safety. The Financial Returns from a Safe Working Environment. 1st Edition, CRC Press, Boca Raton. https://doi.org/10.1201/9780203427927

[5] Koopman, C., Pelletier, R.K., Murray, J.F., Sharda, C.E., Berger, M.L. and Turpin, P. (2006) Health Safety Executive: The Department of Labour. Model for Business, Excellence. Government Printers, Harare.

[6] Kumar, M.P., Mugundhan, K., and Visagavel, K. (2014) Occupational Health \& Safety in Textile Industry. International Journal of Engineering Research and Technology, 3. https://ijret.org/volumes/2014v03/i23/IJRET20140323037.pdf

[7] Islam, R., Hossain, M.S. and Siddique, A.B. (2017) Occupational Health Hazards and Safety Practices among the Workers of Tannery Industry in Bangladesh. Jahangirnagar University Journal of Biological Sciences, 61, 13-22. https://doi.org/10.3329/jujbs.v6i1.33727

[8] Öztaş, A., Güzelsoy, S.S. and Tekinkuşc, M. (2007) Development of Quality Matrix to Measure the Effectiveness of Quality Management Systems in Turkish Construction Industry. Building and Environment, 42, 1219-1228. https://doi.org/10.1016/j.buildenv.2005.12.017

[9] Fernandez-Muniz, B., Montes-Peon, J.M. and Vazquez-Ordas, C.J. (2007) Safety Management System: Development and Validation of a Multidimensional Scale. Journal of Loss Prevention in the Process Industries, 20, 52-68. https://doi.org/10.1016/j.jlp.2006.10.002

[10] Biswas, S. and Rahman, T. (2013) The Effect of Working Place on Worker's Health in a Tannery in Bangladesh. Advances in Anthropology, 3, 46-53. http://www.scirp.org/journal/aa https://doi.org/10.4236/aa.2013.31007

[11] Tasnim, F., Rahman, I., Rahman, M.S. and Islam, R. (2016) A Review on Occupa- 
tional Health Safety in Bangladesh with Respect to Asian Continent. International Journal of Public Health and Safety, 1, 102.

[12] Rongved, A.T. (2011), UNIDO Technical Report on Re-Blading Manual. Re-Tie Bangladesh, UNIDO. 